\title{
Neanderthals had outsize effect on human biology
}

\section{From skin disorders to the immune system, sex with archaic species changed Homo sapiens.}

\section{BY EWEN CALLAWAY}

$\longrightarrow$ ur ancestors were not a picky bunch. Overwhelming genetic evidence shows that Homo sapiens had sex with Neanderthals, Denisovans and other archaic relatives. Now researchers are using large genomics studies to unravel the decidedly mixed contributions that these ancient romps made to human biology - from the ability of H. sapiens to cope with environments outside Africa, to the tendency of modern humans to get asthma, skin diseases and maybe even depression.

The proportion of the human genome that comes from archaic relatives is small. The genomes of most Europeans and Asians are 2-4\% Neanderthal ${ }^{1}$, with Denisovan DNA making up about $5 \%$ of the genomes of Melanesians ${ }^{2}$ and Aboriginal Australians ${ }^{3}$. DNA slivers from other distant relatives probably pepper a variety of human genomes ${ }^{4}$.

But these sequences may have had an outsize effect on human biology. In some cases, they are very different from the corresponding H. sapiens DNA, notes population geneticist David Reich of Harvard Medical School in Boston, Massachusetts - which makes it more likely that they could introduce useful traits. "Even though it's only a couple or a few per cent of ancestry, that ancestry was sufficiently distant that it punched above its weight," he says.

Last year, Reich co-led one of two teams that catalogued the Neanderthal DNA living on in modern-day humans $s^{5,6}$. The studies hinted that Neanderthal versions of some genes may have helped Eurasians to reduce heat loss or grow thicker hair. But the evidence that these genes were beneficial was fairly weak.

To get a better handle on how Neanderthal DNA shapes human biology, Corinne Simonti

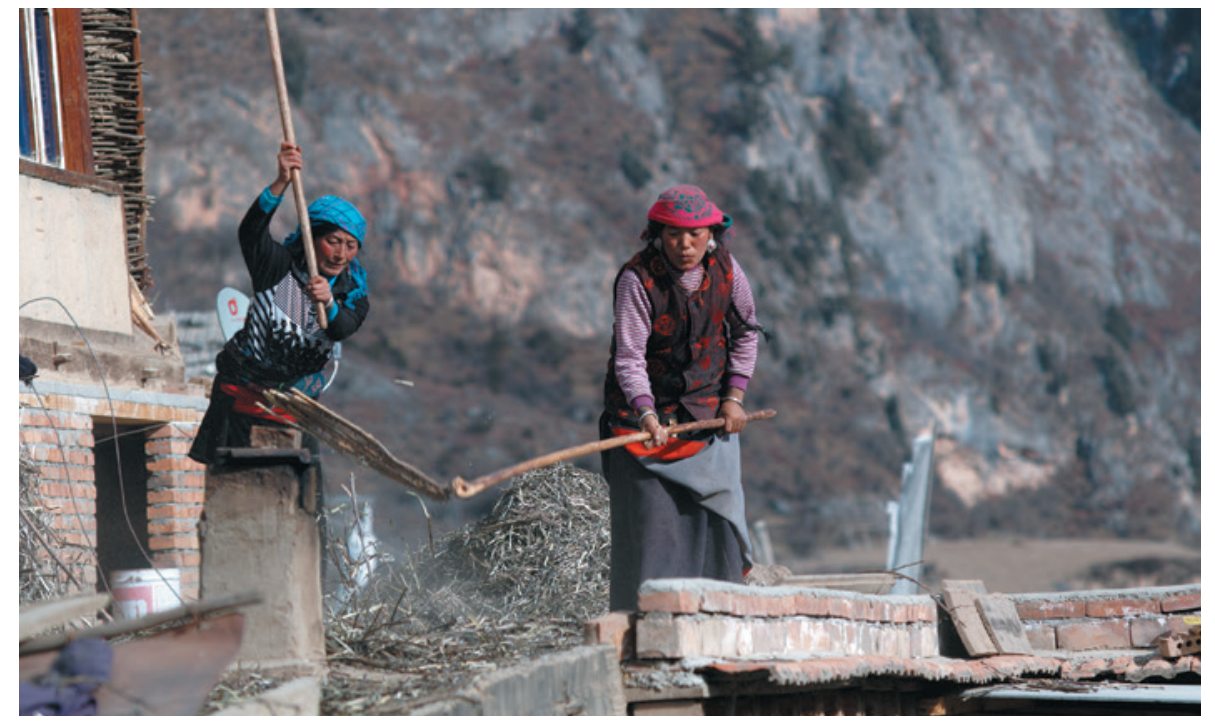

A gene variant from archaic humans helps modern-day Tibetans to cope with high altitudes.

and Tony Capra, evolutionary geneticists at Vanderbilt University in Nashville, Tennessee, turned to genome-wide association studies (GWAS) that had already compared thousands of DNA variants in people with and without a certain disease or condition.

Using de-identified genome data and medical records from 28,000 hospital patients, Simonti and Capra looked for differences in traits and medical diagnoses between people with a particular Neanderthal gene variant and those with the $H$. sapiens version of the same gene. They found that the Neanderthal variants seemed to slightly increase the risk of conditions such as osteoporosis, blood-coagulation disorders and nicotine addiction. Another analysis, which looked at the combined effects of many DNA variants, painted a more mixed picture. It revealed links between Neanderthal DNA and depression, obesity and certain skin disorders, with some variants being associated with an increased risk and others with a reduced risk. Simonti presented the data at the annual meeting of the Society for Molecular Biology and Evolution in Vienna on 15 July.

Neanderthal gene variants, like most human variants, had only a tiny effect on the risk of developing these conditions, notes Capra. But seeing Neanderthal genes involved in skin disorders, including lesions triggered by sun exposure, chimes with previous studies linking Neanderthal DNA to skin biology, he says.

In some cases, the effects of the archaic genes may have changed over the ages. Simonti and Capra also reported at the Vienna meeting that blood-coagulation disorders experienced by modern humans could be related to Neanderthal immune genes, although previous studies
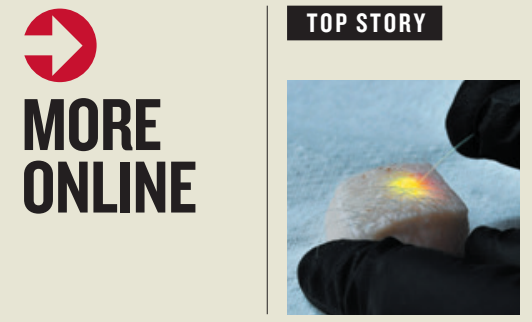

Droplets of oil turn cells into tiny lasers go.nature. com/4vf5fa

\section{MORE NEWS}

- Brain area found that may make humans unique go.nature.com/xxn9p2 - Simple cooking methods flush arsenic out of rice go.nature.com/vl6367 - Scientists unite to warn against flawed chemical reagents go.nature. com/dpttdu
Q\&A

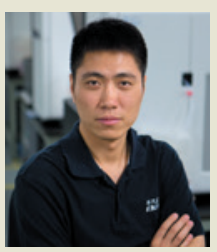

Genomics pioneer Jun Wang on his new venture in artificial intelligence go.nature.com/pupjhy 
have suggested that archaic immune genes may have helped $H$. sapiens to cope with diseases that they encountered outside Africa.

Also at the meeting, a team led by Michael Dannemann, a computational biologist at the Max Planck Institute for Evolutionary Anthropology in Leipzig, Germany, reported that many humans have Neanderthal and Denisovan versions of genes that encode proteins called toll-like receptors (TLRs), which sense pathogens and launch a rapid immune response. Furthermore, cultured human cells containing the archaic versions tended to express the TLRs at higher levels than cells with the $H$. sapiens versions ${ }^{7}$. Although previous GWAS linked the archaic versions to a reduced risk of Heliobacter pylori infection, which can cause stomach ulcers, the variants were also associated with higher rates of allergies.

"Many traits that were adaptive 10,000 years ago might be maladaptive today" because of lifestyle, diet and other shifts, notes Rasmus Nielsen, a population geneticist at the University of California, Berkeley.

At least one archaic trait has clear benefits in contemporary humans. Last year, Nielsen's team reported that the Denisovan-like version of a gene called EPAS1 helps modern Tibetans to cope with life at altitudes of 4,000 metres, by preventing their blood from thickening ${ }^{8}$.

Many researchers see Nielsen's EPAS1 discovery as the poster child for humans' archaic biology, because the benefits of the Denisovan version are so clear-cut. But proving such insights rests on laborious studies, including engineering mice to carry the archaic mutations and exhaustively testing the animals' biology, notes Reich. "Each new finding is going to be very hard won." -

1. Green, R. E. et al. Science 328, 710-722 (2010).

2. Meyer, M. et al. Science 338, 222-226 (2012).

3. Rasmuseen, M. et al. Science 334, 94-98 (2011).

4. Hammer, M. F., Woerner, A. E., Mendez, F. L.,

Watkins, J. C. \& Wall, J. D. Proc. Natl Acad. Sci. USA 108, 15123-15128 (2011).

5. Vernot, B. \& Akey, J. M. Science 343, 1017-1021 (2014)

6. Sankararaman, S. et al. Nature 507, 354-357 (2014).

7. Dannemann, M., Andrés, A. M. \& Kelso, J. Preprint at http://dx.doi.org/10.1101/022699 (2015).

8. Huerta-Sánchez, E. et al. Nature 512, 194-197 (2014).

\section{Budget showdown leaves US science agencies in limbo}

\section{Lawmakers face looming deadline to reach a deal - or risk government shutdown.}

\section{BY CHRIS CESARE}

$\mathrm{W}$ hen the US Congress returns from its late-summer recess in early September, lawmakers and President Barack Obama will have less than three weeks to reach a budget deal for 2016, and in doing so determine the funding of key science agencies.

The most likely scenario, experts say, is that a temporary deal will be made to keep the government operating for weeks or months after the 2016 fiscal year begins on 1 October. That is cold comfort for US science agencies and researchers who have endured years of bruising partisan spending battles.

"We're basically headed into a period of frustration where nothing's going to happen for a couple months, and we're just going to have to deal with it," says Jennifer Zeitzer, director of legislative relations at the Federation of American Societies for Experimental Biology in Bethesda, Maryland.

The current funding agreement expires on 30 September. And, in protest against legislators' embrace of the across-the-board budget cuts known as sequestration, Obama has threatened to veto many of the 2016 spending bills introduced by the Republican-controlled House of Representatives and Senate.

Some agencies, such as the National Institutes of Health (NIH), seem likely to emerge as winners in any deal (see 'Budget battle'). The House has proposed increasing the NIH budget by US\$1.1 billion in

BUDGET BATTLE

How funding proposals from the White House and Congress stack up, by agency (US\$ millions).

\begin{tabular}{|c|c|c|c|c|}
\hline Agency & $\begin{array}{c}2015 \text { estimated } \\
\text { budget }\end{array}$ & $\begin{array}{l}2016 \text { White } \\
\text { House request }\end{array}$ & $\begin{array}{l}2016 \text { House } \\
\text { bill }\end{array}$ & $\begin{array}{l}2016 \text { Senate } \\
\text { bill }\end{array}$ \\
\hline \multicolumn{5}{|c|}{ Biomedical research and public health } \\
\hline National Institutes of Health & 30,311 & 31,311 & 31,184 & 32,084 \\
\hline $\begin{array}{l}\text { Centers for Disease Control } \\
\text { and Prevention }\end{array}$ & 6,073 & 6,170 & 7,010 & 6,711 \\
\hline $\begin{array}{l}\text { Food and Drug } \\
\text { Administration }\end{array}$ & 2,596 & 2,744 & 2,619 & 2,629 \\
\hline \multicolumn{5}{|l|}{ Physical sciences } \\
\hline National Science Foundation & 7,344 & 7,724 & 7,394 & 7,344 \\
\hline NASA (science) & 5,245 & 5,289 & 5,238 & 5,295 \\
\hline $\begin{array}{l}\text { Department of Energy Office } \\
\text { of Science }\end{array}$ & 5,068 & 5,340 & 5,100 & 5,100 \\
\hline $\begin{array}{l}\text { National Institute of } \\
\text { Standards and Technology }\end{array}$ & 864 & 1,120 & 855 & 893 \\
\hline \multicolumn{5}{|l|}{ Earth and environment } \\
\hline $\begin{array}{l}\text { Environmental Protection } \\
\text { Agency }\end{array}$ & 8,140 & 8,592 & 7,422 & 7,597 \\
\hline $\begin{array}{l}\text { National Oceanic and } \\
\text { Atmospheric Administration }\end{array}$ & 5,449 & 5,983 & 5,167 & 5,382 \\
\hline US Geological Survey & 1,045 & 1,195 & 1,045 & 1,059 \\
\hline
\end{tabular}

2016 , to $\$ 31.2$ billion; the Senate's proposal of $\$ 32.1$ billion is even more generous. And both are close to the White House proposal of $\$ 31.3$ billion.

But for other agencies and programmes, the prospects are not so clear. The House matched Obama's \$18.5-billion request for NASA, and the Senate is close at $\$ 18.3$ billion.
But the House wants to chop \$101 million from the space agency's \$1.8-billion Earthsciences account, which funds research on topics such as climate change. The Senate would boost the wing's funding by roughly $\$ 148$ million. Similarly, the House bill would set aside $\$ 5.2$ billion for the National Oceanic and Atmospheric Administration 